\title{
PENGEMBANGAN PERENCANAAN UMKM PRODUKSI TEMPE (HOME INDUSTRI) SAAT COVID-19 DI DESA GUNUNG SULAH
}

\author{
Finkhy Marghareth Valenthine ${ }^{1}$, Suwandi ${ }^{2 *}$, Afitra Kuntum Rahma Ari Prawita ${ }^{3}$ \\ $1,2,3$ IIB Darmajaya, Lampung

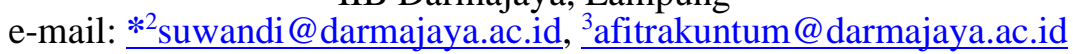

\begin{abstract}
Abstrak
Dalam masa pandemi saat ini ketahanan nasional sangatlah diuji khususnya di bidang ekonomi dan kesehatan. Dalam masa pandemi saat ini Usaha Mikro Kecil Menengah (UMKM) tidak dapat dilepaskan dari terdampaknya pandemi covid-19. Usaha Mikro Kecil Menengah (UMKM) haruslah dapat bertahan di masa pandemi saat ini yang mana dituntun harus mempunyai inovasi lebih untuk meningkatkan daya jual ke masyarakat dengan tetap terus mematuhi protokol kesehatan. Tujuan yang ingin dicapai adalah untuk mengembangkan UMKM Produksi Tempe (Home Industri) bagi pemilik yang terdampak situasi covid-19 melalui suatu perencanaan pengembangan. Metode yang digunakan dalam pengabdian ini adalah pelatihan dan pendampingan UMKM produksi tempe dalam pengenalan bisnis digital, pembuatan merek, memberi inovasi baru terhadap pengemasan produk dan membantu penjualan produk, dan pembuatan social media serta layanan web (google maps). Pada akhirnya, UMKM Tempe yang sebelumnya tidak mempunyai merek pada kemasan, kini sudah memiliki merek kemasan yaitu Tempe Novi, dengan demikian konsumen lebih mudah mengingat nama produk dan tertarik untuk membelinya. Selain itu, dengan adanya layanan web yaitu Google Maps UMKM Tempe dapat dijangkau dengan luas karena bisa memberikan informasi alamat detail, deskripsi UMKM maupun foto-foto produk yang dilampirkan. Semua kegiatan tersebut dapat membantu masyarakat untuk mengenal produk dan meningkatkan nilai jual dari produk UMKM Tempe Ibu Wiwid di Desa Gunung Sulah, membantu meningkatkan perekonomian UMKM selama pandemi covid-19, dan dapat memperluas jangkauan pangsa pasar dari produksi tempe yang dibuat.
\end{abstract}

Kata kunci: Covid-19, Pelatihan dan Pendampingan, Produksi Tempe, UMKM.

\begin{abstract}
During the current pandemic, national resilience is being tested, especially in the economic and health fields. During the current pandemic, Micro, Small and Medium Enterprises (MSMEs) cannot be separated from the impact of the COVID-19 pandemic. Micro, Small and Medium Enterprises (MSMEs) must be able to survive during the current pandemic which is led to have more innovations to increase selling power to the public while continuing to comply with health protocols. The goal to be achieved is to develop Tempe Production SMEs (Home Industries) for owners affected by the COVID-19 situation through a development plan. The method used in this service is training and mentoring SMEs in tempe production in introducing digital businesses, creating brands, providing new innovations for product packaging and helping product sales, and making social media and web services (google maps). In the end, Tempe MSMEs, which previously did not have a brand on the packaging, now have a packaging brand, namely Tempe Novi, so that consumers can easily remember the product name and are interested in buying it. In addition, with a web service, namely Google Maps, SMEs Tempe can be widely accessed because it can provide detailed address information, descriptions of SMEs and photos of attached products. All of these activities can help the community get to know the product and increase the selling value of MSME products Tempe Ibu Wiwid in Gunung Sulah Village, help improve the MSME economy during the COVID-19 pandemic, and can expand the reach of the market share of tempeh production.
\end{abstract}

Keywords: Covid-19, Training and Assistance, Tempe Production, MSMEs. 


\section{PENDAHULUAN}

Sejak awal tahun 2020, hampir semua negara di dunia mengalami hal yang sama yaitu menghadapi virus yang disebut dengan virus Corona atau Covid-19 [1]. Virus ini masuk dalam kategori penyakit yang menyerang sistem pernafasan yang menyebabkan gangguan pada sistem pernapasan, pneumonia akut, sampai kematian [2]. Sektor ekonomi menjadi sektor

yang terdampak cukup parah akibat pandemi covid-19. Pandemi covid-19 yang terjadi di Indonesia sejak awal bulan Maret 2020 telah memaksa sebagian besar masyarakat untuk membatasi aktifitasnya agar penyebaran virus corona dapat dicegah. Hal ini berakibat berbagai sektor terkena imbasnya [3]. Terutama untuk usaha rumah tangga (Home Industry) yang baru terjun dalam dunia bisnis.

Dalam masa pandemi saat ini, Usaha Mikro Kecil Menengah (UMKM) tidak dapat dilepaskan dari terdampaknya pandemi covid-19. Usaha Mikro Kecil Menengah (UMKM) haruslah dapat bertahan di masa pandemi saat ini yang mana dituntun harus mempunyai inovasi lebih untuk meningkatkan daya jual ke masyarakat dengan tetap terus mematuhi protokol Kesehatan [4].

Sejalan dengan situasi dan kondisi pandemi COVID-19 ini, Institut Informatika dan Bisnis (IIB) Darmajaya sebagai perguruan tinggi terbesar di Provinsi Lampung, dimana salah satu Tridharma Perguruan Tinggi adalah melaksanakan pengabdian kepada masyarakat.
Maka, dalam hal ini punya tanggung jawab yang besar untuk juga berkontribusi dalam pencegahan dan penanganan penyebarana COVID-19 ini di masyarakat dengan penerapan berbagai program. Melalui Lembaga Penelitian, Pengembangan Pembelajaran dan Pengabdian Kepada Masyarakat (LP4M), IIB Darmajaya merumuskan kegiatan Praktek Kerja Pengabdian Masyarakat Tematik di Masa Pandemi COVID19. Kegiatan Praktek Kerja Pengabdian Masyarakat (PKPM) merupakan kegiatan yang terjadwal secara akademik di IIB Darmajaya setiap semester. Oleh karena itu, percepatan penanggulangan COVID-19 sangat srategis jika dilakukan melalui kegiatan Kegiatan Praktek Kerja Pengabdian Masyarakat (PKPM) COVID19. Pelaksanaan PKPM merupakan sarana yang memfasilitasi mahasiswa untuk menerapkan teori-teori yang diperoleh di perkuliahan dalam bentuk usaha program kegiatan masyarakat usaha kecil dan menengah yang terletak di desa-desa atau pinggiran kota [5].

Kehidupan bermasyarakat tidak akan terlepas dari tata kelakuan atau sistem budaya. Masyarakat kelurahan Gunung Sulah merupakan penduduk mayoritas dan masyarakatnya masih dikenal taat menjalankan adat istiadat masyarakat. Nama Desa Gunung Sulah merupakan tempat untuk diambil dari salah satu nama bukit yang berada di Bandar Lampung yang dijadikan nama kelurahan di sekitar bukit tersebut. Mayoritas masyarakatnya bersuku jawa yang merupakan masyarakat pendatang (bukan 
transmigran) dari provinsi Jawa Tengah seperti Solo, Yogyakarta, dan Semarang. Pada masyarakat kota di Kelurahan Gunung Sulah, sampai saat ini pelaksanaan riungan masih diadakan. Ini membuktikan bahwa rasa kebersamaan sangat terasa, dan kepentingan pribadi sangat tidak terlihat.

Berangkat dari kondisi itulah sekarang muncul sebuah gagasan baru untuk lebih memberdayakan masyarakat dan potensi yang ada di Desa Gunung Sulah, dimana gagasan tersebut melibatkan masyarakat desa untuk turun langsung di lapangan, baik dalam hal memproduksi, pengemasan dan pengorganisasian. Banyak manfaat yang dapat dirasakan oleh masyarakat di Desa Gunung Sulah baik secara ekonomi maupun non-ekonomi. Dalam banyak kegiatan yang bertujuan untuk peningkatan perekonomian desa, Desa Gunung Sulah banyak terdapat tempat produksi atau Usaha Mikro UMKM dimulai dari produksi Tempe, Tahu, Oncom, Peyek, Kue Pie, dan lainnya.

UMKM merupakan suatu usaha perdagangan yang dikelola oleh perorangan atau juga badan usaha yang dalam hal ini termasuk juga sebagai kriteria usaha dalam lingkup kecil atau juga mikro [6]. Kondisi persaingan pasar yang kompetitif menjadi aspek yang tidak lepas dari perhatian, mereka harus saling bersaing untuk mampu menjadi yang diminati pasar, belum lagi harus bersaing dengan perusahaan besar. Alasan para pelaku bisnis UMKM mempertimbangkan aspek mutu dan kualitas tentu salah satunya dikarenakan kesadaran mereka terhadap konsumen dan calon konsumen yang selektif sebelum melakukan keputusan pembelian [7]-[9].

Salah satunya UMKM Tempe yang masih memiliki kekurangan seperti tidak memiliki merek pada produk, kurangnya pengetahuan terhadap teknologi pemasaran. Dengan kurangnya sumber daya manusia untuk mengembangkan inovasi agar produk lebih menarik, timbul motivasi dari PKPM IIB Darmajaya untuk membangun dan mengembangkan produk Tempe milik Ibu. Dwi Widyawati. Sehingga, berdasarkan latar belakang di atas, pengabdian ini bertujuan untuk mengembangkan UMKM Produksi Tempe (Home Industri) bagi pemilik yang terdampak situasi covid-19 melalui suatu perencanaan pengembangan.

\section{METODE}

Metode pelaksanaan kegiatan pengabdian masyarakat ini adalah penyuluhan, pelatihan dan pendampingan dalam pengenalan bisnis digital, pembuatan merek, memberi inovasi baru terhadap pengemasan produk dan membantu penjualan produk, dan pembuatan social media serta layanan web (google maps). Subjek pengabdian ini adalah UMKM milik Pak Novi di Desa Gunung Sulah Kec. Way Halim, Bandar 
Lampung. Kegiatan ini dilakukan selama 5 minggu dengan rincian sebagai berikut :

Tabel 1. Rencana Kegiatan

\begin{tabular}{|c|c|c|}
\hline $\begin{array}{l}\text { Minggu } \\
\text { ke- }\end{array}$ & Tanggal & Kegiatan \\
\hline \multirow[t]{2}{*}{1} & 16 Agustus 2021 & $\begin{array}{l}\text { Pertemuan dengan RT dan } \\
\text { pemilik usaha UMKM }\end{array}$ \\
\hline & 18 Agustus 2021 & 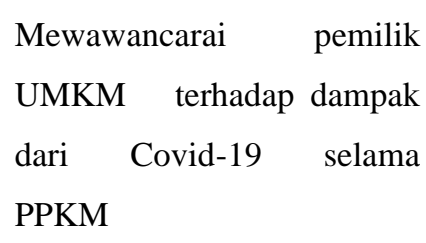 \\
\hline \multirow[t]{2}{*}{2} & 23 Agustus 2021 & $\begin{array}{l}\text { Ikut serta dalam membantu } \\
\text { pengemasan pembuatan } \\
\text { tempe pada UMKM }\end{array}$ \\
\hline & 27 Agustus 2021 & $\begin{array}{l}\text { Mensurvei lapangan dalam } \\
\text { proses jual beli tempe di } \\
\text { pasar Way Halim }\end{array}$ \\
\hline \multirow[t]{2}{*}{3} & 1 September 2021 & $\begin{array}{l}\text { Membantu pengepakan } \\
\text { tempe yang sudah siap untuk } \\
\text { dijual belikan }\end{array}$ \\
\hline & 2 September 2021 & $\begin{array}{l}\text { Memperkenalkan bisnis } \\
\text { digital kepada UMKM } \\
\text { Tempe }\end{array}$ \\
\hline \multirow[t]{2}{*}{4} & 8 September 2021 & $\begin{array}{l}\text { Pembuatan merek/logo } \\
\text { kepada UMKM }\end{array}$ \\
\hline & 9 September 2021 & $\begin{array}{l}\text { Pembuatan google maps } \\
\text { kepada UMKM }\end{array}$ \\
\hline \multirow[t]{2}{*}{5} & 13 September 2021 & $\begin{array}{l}\text { Membantu pengemasan } \\
\text { tempe }\end{array}$ \\
\hline & 14 September 2021 & $\begin{array}{l}\text { Membantu proses pembuatan } \\
\text { tempe }\end{array}$ \\
\hline
\end{tabular}

\section{HASIL DAN PEMBAHASAN}

Kegiatan pertama yang dilakukan adalah pengenalan tentang bisnis digital, kegiatan ini diperkenalkan kepada pemilik UMKM untuk memperkenalkan materi tentang Bisnis Digital guna untuk meningkatkan pangsa pasar bagi pengusaha dan mengurangi biaya, misalnya distribusi atau promosi. Pada kegiatan ini, pemiilik UMKM terlihat antusias dalam mendengarkan pemaparan dari pemateri mengenai bisnis digital.

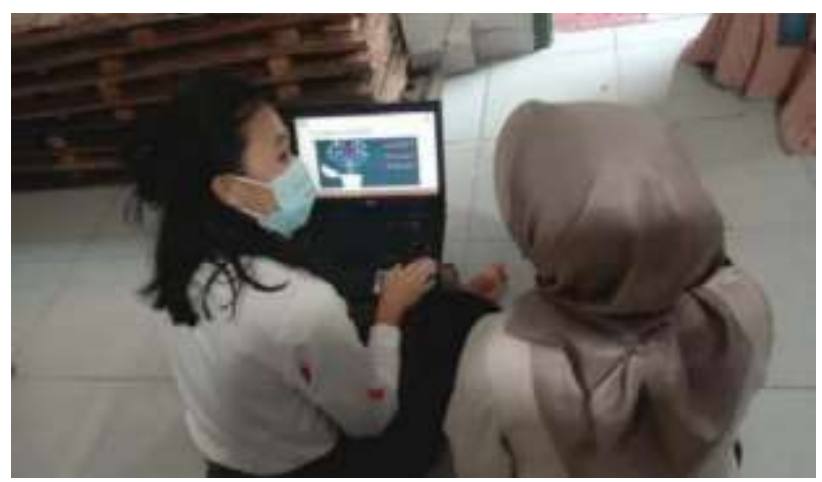

Gambar 1. Pengenalan Bisnis Digital kepada pemilik UMKM

Pada kegiatan selanjutnya, dilakukan pendampingan dalam pembuatan merk, logo, serta kemasan dari UMKM milik Bapak Novi. Dalam menamai produk, pengabdi tentunya meminta izin kepada Ibu Dwi Widyawati selaku pemilik UMKM Tempe, untuk dapat memberikan saran Merek untuk produknya. pengabdi memberikan usulan "Tempe Novi". Hal itu dikarenakan nama Novi ialah nama suami dari ibu Dwi Widyawati dan juga selaku pemilik UMKM Produksi Tempe.

Tidak hanya merek, pengabdi juga memberikan saran berupa logo dari merek tersebut. Merek yang dibuat tidak jauh dari nama "Novi", karena logo merupakan tanda tangan dari sebuah merek yang menjadi indentitas pembeda dari para kompetitor. Sama dengan pemberian saran merek, pengabdi juga memberikan 
beberapa pilihan dari logo yang cocok dengan merek yang telah diberikan. Tentunya logo yang pengabdi berikan mempunyai filosofi yang sesuai dengan inisial nama pemilik UMKM Tempe tersebut.

Kemudian dari segi kemasan, dengan kondisi saat ini harga kedelai yang menjulang tinggi sehingaga pengembang melalui perencanaan dibuat. Pengabdi dan juga Ibu Dwi Widyawati memutuskan untuk mengganti atau memperkecil ukuran kemasan menjadi 10 x 12 dengan harga yang sama. Guna agar permintaan tetap naik. Kemasan yang pengabdi buat juga tertera logo dari merek yang kami buat dengan tujuan sebagai pemasaran tidak langsung sekaligus membentuk citra merek dari produk yang dihasilkan.
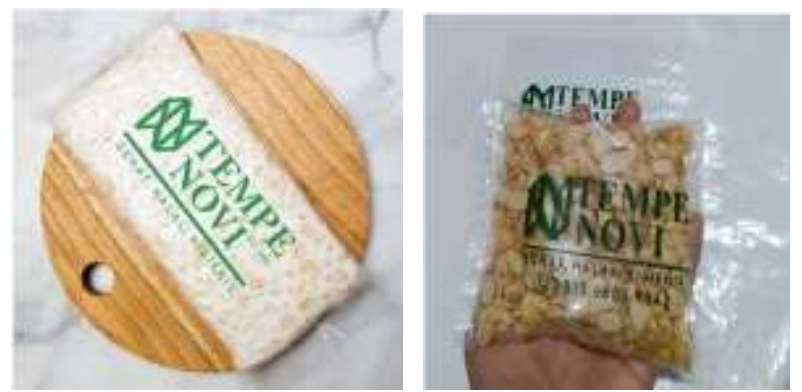

Gambar 2. Merek dan Logo UMKM Tempe (Home Industri)

Kegiatan selanjutnya adalah pembuatan akun social media dan layanan google maps bagi usaha UMKM Produksi Tempe Pak Novi. Ada berbagai macam jenis media sosial di antaranya adalah facebook, twitter, dan instagram. Di antara ketiga media sosial tersebut pengabdi memutuskan untuk memilih instagram sebagai media pemasaran untuk UMKM Tempe. Hal tersebut di karenakan pengguna instagram dari waktu ke waktu meningkat.

Untuk mempromosikan dan meningkatkan eksistensi produk UMKM Tempe maka pengabdi memutuskan untuk membuatka akun yang menunjang kegiatan tersebut. Terlebih dahulu pengabdi meminta izin kepada Ibu Dwi Widyawati sebagai pemilik UMKM untuk membuat akun instagram sebagai media promosi.

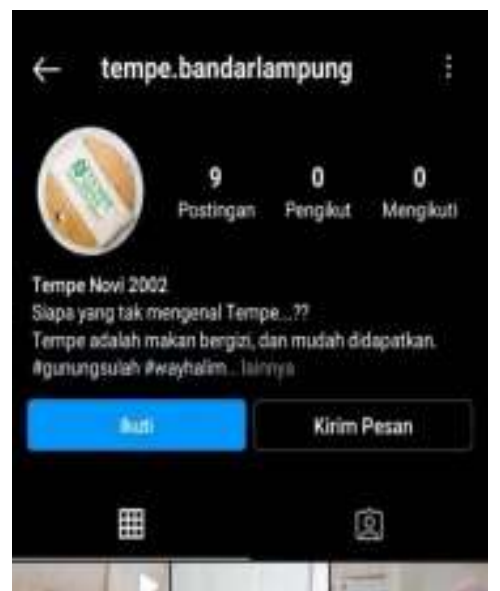

Gambar 3. Akun Instagram UMKM Produksi Tempe Novi

Sedangkan untuk pemetaan google maps, Hal ini sangat tepat digunakan oleh UMKM tentunya pada UMKM Tempe karena informasiinformasi seperti detail alamat lokasi yang lengakap, kontak yang bisa dihubungi, situs web, deskripsi bisnis, hingga foto-foto toko dan produk dapat dihadirkan di Google Maps. Jika sudah muncul di Google Maps, Reputasi toko akan dianggap bagus oleh pelanggan. 


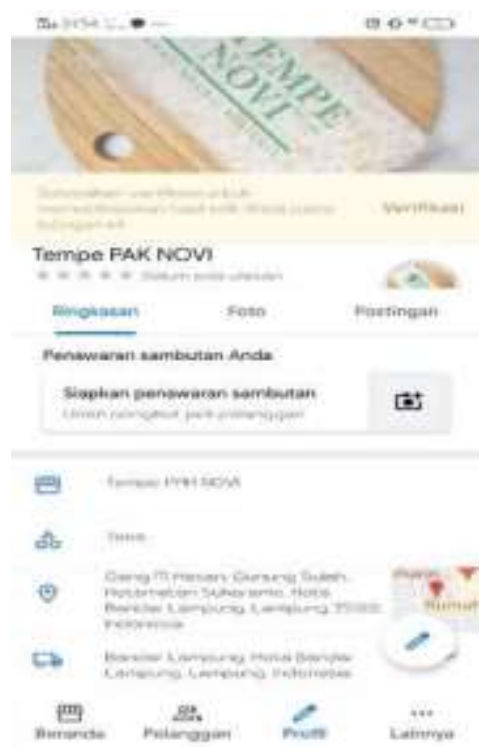

Gambar 4. Tampilan Toko Produksi Tempe Novi pada Google Maps

Selain dari ketiga kegiatan utama yang sudah dijelaskan di atas, pengabdi juga ikut dalam membantu pengemasan tempe. Membantu pemilik UMKM Tempe dalam pengemasan Tempe ialah sebagian dari rangkaian kegiatan rutinitas pada UMKM. Di desa Gunung Sulah mayoritas penduduknya adalah para pedagang yang berproduksi sendiri, seperti usaha produksi tempe, tahu, peyek, oncom, kemplang, kue pie dan lainnya. Dengan adanya kegiatan tersebut merupakan salah satu cara untuk menstabilkan perekonomian para pedagang.

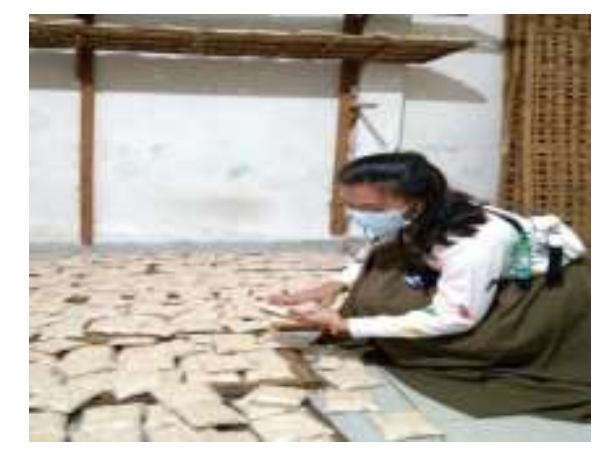

Gambar 5. Pengabdi melakukan proses pengemasan
Pada Akhirnya, UMKM Tempe yang sebelumnya tidak mempunyai merek pada kemasan, kini sudah memiliki merek kemasan yaitu Tempe Novi, dengan demikian konsumen lebih mudah mengingat nama produk dan tertarik untuk membelinya. Selain itu, dengan adanya layanan web yaitu Google Maps UMKM Tempe dapat dijangkau dengan luas karena bisa memberikan informasi alamat detail, deskripsi UMKM maupun foto-foto produk yang dilampirkan.

\section{SIMPULAN}

Berdasarkan uraian kegiatan diatas, pelaksanaan kegiatan ini menghasilkan UMKM Tempe yang sebelumnya tidak mempunyai merek pada kemasan, kini sudah memiliki merek kemasan yaitu Tempe Novi, dengan demikian konsumen lebih mudah mengingat nama produk dan tertarik untuk membelinya. Selain itu, dengan adanya layanan web yaitu Google Maps UMKM Tempe dapat dijangkau dengan luas karena bisa memberikan informasi alamat detail, deskripsi UMKM maupun foto-foto produk yang dilampirkan. Semua kegiatan tersebut dapat membantu masyarakat untuk mengenal produk dan meningkatkan nilai jual dari produk UMKM Tempe Ibu Wiwid di Desa Gunung Sulah, membantu meningkatkan perekonomian UMKM selama pandemi covid-19, dan dapat memperluas 
jangkauan pangsa pasar dari produksi tempe yang dibuat.

\section{SARAN}

Berdasarkan kegiatan yang sudah dilakukan, pengabdi berharap untuk kedepannya untuk meningkatkan rasa kepedulian antar masyarakat untuk saling mengingatkan untuk menjaga kesehatan, kebersihan dan protokol Kesehatan terutama bagi masyarakat yang bermata pencaharian seperti UMKM produksi Tempe ini. Selalu tingkatkan motivasi agar selalu bersemangat di setiap keadaan, bahwa zaman semakin mudah dengan adanya teknologi informasi saat ini bahkan pandemi saat ini bukan menjadi suatu hambatan. Oleh karena itu, para pemilik UMKM harus mengerti dan paham dalam penggunaan teknologi saat ini

\section{DAFTAR PUSTAKA}

[1] I. K. Sakharina, "Hak Atas Pangan di Masa Pandemi Coronavirus Disease Covid-19," Legislatif, vol. 3, no. 2, pp. 367-384, 2020.

[2] J. A. Dani and Y. Mediantara, "Covid-19 dan Perubahan Komunikasi Sosial," Persepsi Commun. J., vol. 3, no. 1, pp. 94102, 2020, doi: 10.30596/persepsi.v3i1.4510.

[3] R. Rosita, "Pengaruh Pandemi Covid-19 Terhadap Umkm Di Indonesia," J. Lentera Bisnis, vol. 9, no. 2, p. 109, 2020, doi: 10.34127/jrlab.v9i2.380.

[4] S. Setioko, Y. Fitriani, and K. Munawaroh, "Strategi Peningkatan Usaha Kecil Mikro dan Menengah (UMKM) di Era PandemiCovid-19 Pada Kota Metro," J. Community Dev., vol. 2, no. 2, pp. 60-65, 2021.

[5] Abdulloh, A. Kurniawan, M. Kurniawan, and F. Fuadi, "Pemberdayaan masyarakat melalui usaha rumahan produksi kelanting," Al-Mu'awanah J. Pengabdi. Kpd. Masy., vol. 2, no. 1, pp. 29-41, 2021.

[6] I. F. Maizir, P. A. Al-khairi, and A. D. Sari, “Analisis Lingkungan Tempat Kerja Dalam Peningkatan Produktivitas Pada Umkm Konveksi XYZ Dengan Menggunakan Metode 6S," IENACO (Industrial Eng. Natl. Conf., vol. 8, pp. 8995, 2020.

[7] W. W. Aji, "Dampak Pelatihan Makanan Ringan Pada Kelompok Usaha Micro, Kecil dan Menengah (UMKM) Bagi Pemberdayaan Ekonomi Masyarakat di Desa Sukaluyu ...," JoCE (Journal of Community Education), vol. 2, no. 2. pp. 8-12, 2021, [Online]. Available: https://journal.unsika.ac.id/index.php/joce /article/download/4387/2626.

[8] M. A. Putri, Rosmayani, and Rosmita, "Analisis Faktor-Faktor Mempengaruhi Salur Distribusi Usaha Kecil Menengah (Survei Pada Kue Bangkit 'Syempana' Di Kota Pekanbaru)," J. Valuta, vol. 4, no. 2, 
pp. 116-137, 2018.

[9] Sulistiyani and A. Pratama, "Analisis

Strategi Pemasaran UMKM Di Era

Industri," J. Pemasar. Kompetitif, vol. 5,

no. 1, pp. 113-123, 2021, doi:

10.46367/iqtishaduna.v8i2.175. 